\title{
A Tribute to Hubert ("Hue") Norman MacKenzie, 1922-2009
}

\author{
DANIEL F. BRUNTON
}

216 Lincoln Heights Road, Ottawa, Ontario K2B 8A8 Canada; e-mail: bruntonconsulting@rogers.com

Brunton, Daniel F. 2011. A Tribute to Hubert ("Hue”) Norman MacKenzie, 1922-2009. Canadian Field-Naturalist 125(1): 76-79.

Gentlemanly ... that would probably be the most common summation offered by those of us who were privileged to work with Hubert ("Hue") MacKenzie (Figure 1) during his years with the Ottawa FieldNaturalists' Club (OFNC). Hue served the OFNC in many capacities, including an exceptionally busy fouryear period as President in the late 1960s. It is probably fair to say that he entered into his association with the OFNC simply as a budding naturalist keen on improving his knowledge of birds and plants (especially orchids). While he certainly achieved that, within short order his involvement and commitment evolved into that of an important official within the organization and a leader of its awakening conservation consciousness.

Hue was born in Vancouver, British Columbia, on 2 April 1922 and was raised in that area. He attended Burnaby High School until 1940 and provided World War II service in the Canadian Army (1942-1946). He moved to Ottawa in 1949 to join the federal civil service where he met and married Ottawa Valley resident Elva Maitland. In the early 1950s they moved back to western Canada where Hue studied at the University of British Columbia while Elva worked as a school teacher. It was in this time that they became keenly interested in both the study of natural history and in travel, activities they kept up throughout their marriage (Brenda Wilson, personal communication). They returned to Ottawa about 1960 both in response to a desire to return to Elva's geographic roots and to further Hue's career as a statistician. He worked within Supply and Services Canada and its predecessors for the rest of his professional career, retiring as Chief of Section in 1980. Although fellow statistician and future OFNC President Frank Pope knew Hue during their overlapping careers in "Stats Can", neither was aware of the other's natural history interests (Frank Pope, personal communication).

Hue and Elva joined the Ottawa Field-Naturalists in May 1962 to further enhance and develop the skills and interests they had developed in British Columbia. Although interested in birds in a general way since childhood, Hue became seriously interested in birding at this time (Coope 2002). The timing of their involvement was fortuitous for the OFNC. This was just as the Club was to feel the first wave of environmental awareness that was sweeping the western world in that decade and major changes in the organization were afoot (Brunton 2004). Within short order his involved and steady approach to Club matters was apparent and he and Elva became fixtures at Club events (especially birding field trips). Soon thereafter (December 1963), Hue was elected a member of Council and began a long period of contribution to the organizational and administrative needs of the OFNC. This included terms as Vice-president (1965-1966) and President (19661969). One of the unglamourous but very important of these initiatives was chairing a special Council committee to revise and update the OFNC constitution in 1967 along with Ted Mosquin, Victor Solman, and Rowley Frith.

It is probably fair to say that he came to the development of conservation awareness gradually during this period. It was likely through the MacKenzies' field investigations for birds and native orchids that Hue became increasingly ecologically aware and conservation oriented. Working with a group led by orchid specialist Edward Greenwood (Reddoch and Reddoch 2002) he became active in efforts to protect important populations of locally uncommon species as the decade wore on. He was very involved, for example, in the effort to protect the large population of Pink Ladyslipper (Cypripedium acaule) in the National Capital Greenbelt lands north of Corkstown Road in Nepean (now western Ottawa) in 1967 (LAC OFNC, 6 June 1967).

Hue also served as OFNC representative to the founding meeting of the Canadian Environmental Council (LAC OFNC, 17 September 1969). Although agreeable to and involved with relatively low-key, "bureaucratic" conservation initiatives in the National Capital Greenbelt and elsewhere in the mid-1960s (LAC OFNC, 1 March 1968), he was not convinced that the OFNC should join the conservation activist movement that was sweeping the continent in that decade. He spoke against such an activist approach, for instance, in regards to the increasingly urgent conservation needs of Gatineau Park (LAC OFNC, 6 December 1966).

That perspective evolved in the late 1960 s and by the early 1970s, however, Hue could (and would) be both stubborn and impatient in his promotion and encouragement of the growth of conservation awareness within and beyond the Club. In October 1970, for example, he worked directly with Regional Municipal- 


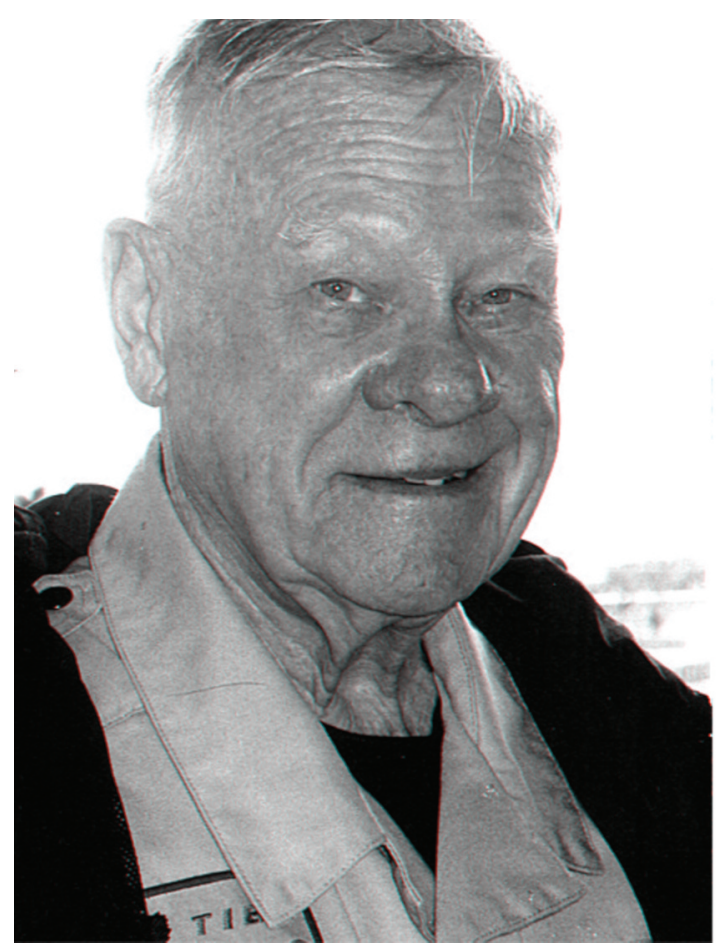

FigURE 1: Hue MacKenzie (17 May 2006) (courtesy of Jo Ann MacKenzie)

ity of Ottawa-Carleton officials in refining the boundaries of a system of conservation areas originating from a submission by the OFNC Conservation Committee (LAC OFNC, 8 October 1970).

MacKenzie was founding chair of the Natural Areas Committee in 1970, overseeing the establishment of the Terms of Reference for the group. It is from this that the present-day Conservation Committee arose. His actions in the late 1960s and 1970s, along with those of fellow activists Sheila Thomson, Ted Mosquin, Anne and Gary Hanes, Donald Smith and a number of others cleared substantial, early portions of the Club's conservation pathway. Within a few years the dynamic OFNC conservation group had become the primary independent conservation interest in western Quebec and eastern Ontario. It remained the most important and persuasive voice for citizen conservation action in this area for at least two decades (arguably, excluding the important Gatineau Park issue which was also being addressed by an new, exclusively conservationoriented organization).

Perhaps the most notable single OFNC achievement during MacKenzie's term as OFNC President, however, was the launching of Trail \& Landscape (T\&L) as the replacement for the chatty but largely unsubstantial OFNC Newsletter (Figure 2). The need for a regularly produced, science based and informative regional

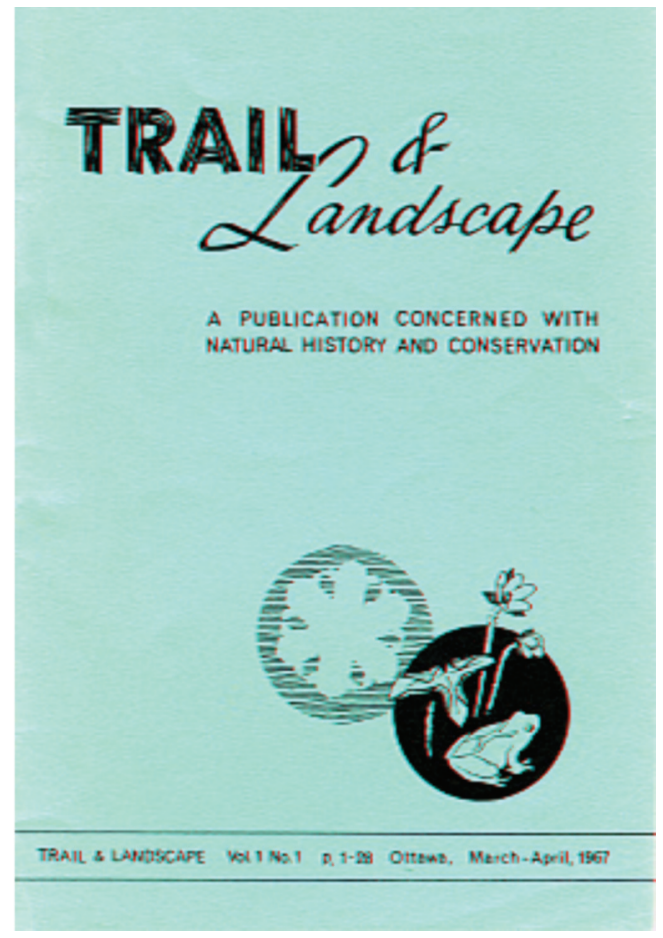

FiguRE 2: First issue of Trail \& Landscape.

publication was huge. The proposal for the creation of such a publication was made by Ted Mosquin at MacKenzie's first OFNC Council meeting as President (LAC OFNC, 5 January 1967). While Mosquin, Sheila Thomson and inaugural T\&L editor Anne Hanes provided the ideas and creative spark for the publication, MacKenzie's Council provided the administrative and logistical support to make it happen.

The launch of T\&L that year was immediately reflected in a surge in OFNC membership. Club membership had increased steadily through the post-war period but it rose exponentially with the complimentary encouragements of a continent-wide awakening to natural history and to conservation matters. T\&L offered the regional voice for such concerns (Brunton 2004). Over 40 years later T\&L remains an important reference source - an ecological corporate memory for the Ottawa Valley, as it were - into which new, significant contributions continue to be added.

The OFNC reached its Centennial in 1979, an important milestone for what was already Canada's largest and oldest regional natural history organization. MacKenzie was not the designer of Centennial celebration plans, some of which were initiated in the 1960s. From the mid-1970s onward, however, Hue was the primary coordinator of the numerous elements that made up that undertaking. OFNC Centennial projects 
included special publications such as the second edition of John Macoun's long out-of-print autobiography (Macoun 1979) and the remarkable, scholarly index to the predecessors of the Canadian Field Naturalist (Gillett 1980). There were also special celebratory assemblies, Centennial excursions, historical explorations and various other tributes acknowledging the contributions of Canada's oldest and largest regional natural history organization.

It was a mammoth task to co-ordinate this all-volunteer effort. As Centennial Committee Chairman Hue actively and successfully directed activities up to and well after the year in question. He stayed on as Centennial Committee chairman until 1981 when everything was wrapped up.

Hue's interest in orchids was spurred on by Ed Greenwood's 1966 establishment of the Native Orchid Location Survey initiative in the Ottawa District. Soon expanded to national coverage, this initiative accumulated data on the location and size of thousands of orchid populations across Canada (Reddoch and Reddoch 2002). Working with fellow enthusiasts such as Greenwood and Joyce and Allen Reddoch, Hue and Elva made major contributions of original data. They submitted hundreds if not thousands of observations, making significant distributional discoveries in the process (e.g., MacKenzie and Greenwood 1969). Hue served as National Coordinator for the program from 1969 through 1974.

Following the end of his marriage to Elva in the 1970s, Hue married fellow birder and active OFNC member Jo Ann Murray. The two became a fixture of the Canadian birding scene (especially on the West Coast) for another thirty years. They moved to Burnaby, British Columbia in 1983, subsequently taking up residence in Surrey in 1985.

In retirement in western Canada Hue remained active both in natural history investigation and in the development of supporting organizations both at home (Vancouver Natural History Society, White Rock and Surrey Naturalists, etc.) and abroad. He was a founding member of the British Columbia Field Ornithologists in 1991. Hue was co-ordinator for the White Rock Christmas Bird Count for many years (he participated in over 75 Christmas Counts) and co-ordinated a 19851986 Spotted Owl survey in southern British Columbia (Coope 2002).

As well as bird conservation issues such as habitat protection, rare species management and population surveys, the MacKenzies were keenly interested in the recreational aspects of birds ("listing"). They accumulated some of the largest of Canadian life list totals, both topping 510 species by the early 2000s. Their birding focus became increasingly international in later years, with birding excursions to over 20 countries. At the time of his death Hue's world "life list" stood at an impressive 4433 species (Jo Ann MacKenzie, personal communication). With a particular inter- est in Southeast Asia, he was especially active with the International Taiwan Birding Association.

Hue MacKenzie was awarded an OFNC Honorary Membership in 1983 in recognition of his critical role with the Club Centennial organization and for his important pioneering contribution to the conservation agenda of the OFNC. The award recognized how pivotal he was in developing a more hands-on approach within this essentially conservative organization. Many prominent member of the day (himself included initially) had argued that bold conservation action had no role in organizations like the OFNC. Hue's quiet persuasion won the day (mostly) and the Ottawa Valley is better for it.

Hue died in Surrey, British Columbia on 4 November 2009 of an asbestos-related cancer that may have been triggered many years before, in his late teens or early 20 s, when he worked one summer in contact with the material on a ship. He is survived by his wife Jo Ann (Murray) MacKenzie and step-daughters Linda Murray and Carol Murray, all British Columbia residents.

Hue Mackenzie's contribution to Club affairs is wonderfully summed up by a line in his Honorary Membership citation, "... it is difficult to point to a major Club activity over the past two decades that has not profited from the 'The MacKenzie Touch"' (Gummer 1983). Hue was “... an inspiration to a whole generation of new Ottawa area naturalists" (Brunton 2004), this author included, and an energizing and encouraging voice to many of us in those rapidly changing times.

\section{Acknowledgements}

My thanks for discussions and input about Hue MacKenzie and his times from former OFNC Presidents Sheila Thomson, Frank Pope, Ted Mosquin and Roger Foxall. Canadian Field-Naturalist Editor Francis Cook, former Trail \& Landscape editor Joyce Reddoch and zoologist Martin McNicholl also provided valuable insights and information. Brenda Wilson of Ottawa, Ontario also provided valuable background on her cousin Elva (Maitland) MacKenzie (deceased 13 May 2008) and on Hue MacKenzie's early Ottawa years. Finally, my thanks to Jo Ann MacKenzie who offered much useful information, especially in regards to his post-Ottawa years, and kindly consented to the use of the photo of Hue.

\section{Documents Cited}

LAC OFNC Collection. The Ottawa Field Naturalists' Club Collection [Council Minute books and documents] (MG 28 I 31), Library and Archives Canada, Ottawa.

\section{Literature Cited}

Brunton, D. F. 2004. Origins and History of The Ottawa Field-Naturalists' Club. Canadian Field-Naturalist 118: 138.

Coope, M. 2002. VNHS Profile; Hue and Jo Ann MacKenzie; Outstanding Birders. Discovery 31(1): 6-10. 
Gillett, J. M. 1980. Transactions of the Ottawa Field-Naturalists' Club and the Ottawa Naturalist Index. Special Publication 2, Ottawa Field-Naturalists' Club, Ottawa.

Gummer, W. G. 1983. Honorary Membership and 1983 Ottawa Field-Naturalist's Club Awards. The Canadian FieldNaturalist 97: 461-462.

Macoun, J. 1979. Autobiography of John Macoun, Canadian Explorer and Naturalist 1831-1920 (Second edition). Special Publication 1, Ottawa Field-Naturalists' Club, Ottawa.
MacKenzie, H. N., and E. W. Greenwood. 1969. Range Extensions of Listera auriculata Wiegand in Ontario and Quebec. Canadian Field-Naturalist 83: 55-56.

Reddoch, J. M., and A. H. Reddoch. 2002. A Tribute to Edward Warren Greenwood (1918-2002), Canadian Orchidologist. Canadian Field-Naturalist 115: 326-330.

Received 31 December 2010

Accepted 13 January 2011 